missible, but there are cases on record where such materials have been used, apparently with disastrous results. Thus there is every reason for investigating those rocks which are potentially vulnerable to dimensional instability when emplaced as aggregates in concrete, and especially the role of the mechanism set up by shrinkage in causing distress and ultimate breakdown. This problem has recently been successfully tackled by $\mathrm{H}$. Roper, J. E. Cox and B. Erlin, in a joint paper entitled "Petrographic Studies on Concrete Containing Shrinking Aggregate" (Journal of the P.C.A. Research and Development Laboratories, 6, No. 3; September 1964. Pp. 2-18. Portland Cement Association Research and Development Laboratories, Skokie, Illinois). As the title implies, the approach to the problem of shrinkage of aggregates is essentially petrographic; it has been shown that this technique is useful in detecting and diagnosing distress in concrete, also in supplying new information leading to a more complete understanding of the phenomena involved.

Two extreme cases of aggregates known to possess high-shrinkage properties resulting from water loss were chosen for this investigation, both from Karroo System of South Africa. These materials were used because their physical properties have been thoroughly studied; they were used in a distressed building, which initiated investigations on excessive dimensional instability, and it was considered important to use materials which had given rise to the largest shrinkages recorded. The material used as coarse a.gregate was the Adendorp Sandstone, from a quarry in Cape Province, Union of South Africa, with a water absorption of 5.78 per cent; the fine aggregate was Kruidfontein Sand, with a water absorption of 4.17 per cent. Petrological studies of concretes made from these aggregates show that internal cracking of the mass has resulted from shrinkage of the aggregate; cracking occurs around aggregate particles and is sometimes modified by the relative positions of adjacent particles. The various stages of cracking and disruption of concrete due to this mechanism are convincingly illustrated in this paper in a series of ground sections of specimens examined, accompanied by interpretative diagrams showing the precise relationships between peripheral, to a lesser extent radial, erack developments and the aggregate particles causing the trouble. An important general observation is made in this paper; it appears from the examination of many concrete aggregates that rocks prone to excossive shrinkage when used for this purpose often contain clay minerals, which may occur as matrix materials, as alteration products of minerals due to weathering, or to the formation of secondary unstable minerals under hydrothermal conditions (for example, chlorophaeite in the case of some basie igneous rocks).

\section{Reactivation of the Hijaz Railway, Saudi Arabia}

ONE of the world's most famous railways, the Hijaz Railway, linking Esh Sham (Damascus) in Syria, Amman in Jordan, and Medina in Saudi Arabia, and its contemporary roactivation, is the subject of an interesting and well-illustrated article by Daniel da Cruz, entitled appropriately "Pilgrim's Road", and published in as special issue of Arameo World (16, No. 5; September-Oetober, 1965. Arabian American Oil Company, New York, 10022). This was originally an Ottoman Empire project designed to link Damascus with Medina and Mecca, and destined to follow the centuries-old pilgrims' route through the then forbidding country of Hijaz, bordering the Red Sea. Construction of the Hijaz Railway commenced in May 1900; by September 1901 the first section, DamascusDer'a, was completed; a year later the Der'a-Zarqua section was opened, to be followed by the extension to Amman in 1903, thence to $\mathrm{Ma}^{\prime}$ an in 1904, Tabuk in 1906, Mada'in Salih in 1907, reaching Medina in 1908. For various political reasons it was not prolonged to Mecca. Thus, in the course of eight years the Turks had put down 808 miles of rail, a remarkable engineering feat considering the nature of the country, the climate, and the attitude of often hostile inhabitants. But the aspirations of the promoters of this worthy project were doomed, largely because of the advent of the First World War when Turkey sided with the Central Powers and her occupation of the Middle East threatened the Suez Canal, along which passed the vital lifeline between Britain and her maritime bases in the Far East. Following the Allied capture of Aqaba, many Turkish locomotives and many miles of track were destroyed; travelling on this railway became an uncertain adventure; civilian traffic languished, and with the termination of hostilities, ceased altogether. After 1918 the Allies set about repairing as much of the line as possible; so much so that despite many vicissitudes, a fairly regular service on the Damascus-Ma'an section has been maintained up to the present day. But rehabilitation of this famous railroad was inevitable, especially on the long-abandoned Ma'anMedina section. Following the independence of Syria and Jordan, an Executive Committee for Recommissioning the Hijaz Railroad Line was established, representing Svria, Jordan and Saudi Arabia; a re-survey was under. taken in 1956 , culminating with a contract being placed for the necessary reconstruction in 1963. Work began in March 1964, and if the projected schedule is met, there is every reason to anticipate this reactivation towards the end of 1966. Apart from the details of this Hijaz Railway scheme, this number of Aramco World, entirely devoted to Saudi Arabia, contains other articles, and a remarkably fine series of coloured and black-and-white photographic illustrations which bring to life glimpses of "Arabia the Beautiful", as it is herein described, but equally leave little to the imagination of what the founding and now the revitalizing of the Hijaz Railway have really meant in terms of human effort and achievement.

\section{National Institute of Agricultural Engineering: Com- ponent Failure Investigation}

A 'COMPONENT failure investigation' service has been started at the National Institute of Agrieulture to enable a manufacturer who is investigating the cause of failure of a component in an agricultural machine to draw on experience accumulated in the course of machinery testing and research and on the facilities available at the Institute. The work done by the Institute, which is on a confidential basis, can include laboratory examinations, calculations and possible rig testing, but any extensive field tests or collection of information about machines in service will normally be carried out by the manufacturer. A consultation fee of from $£ 5$ to $£ 20$ will be charged for the initial examination, which will be based on written evidence and samples supplied by the manufacturer. If further work is needed, a programme and cost estimate will be agreed between the manufacturer and the In. stitute, and the closest possible liaison will be maintained throughout the work. The new service, which has been welcomed by the Agricultural Engineers' Association, will be operated by the Materials Engineering Section of the Engineering Division, National Institute of Agricultural Engineering, Silsoo, Bedfordshire, from which further details can be obtained.

\section{Pollen Studies in New York State}

AN ambitious and well-planned attempt to reconstruct the vegetational and climatic events from late glacial into post-glacial and recent times is recorded in Bulletin 397 of the New York State Museum and Science Service (Pollen Studies in the Crusoe Lake Area of Prehistoric Indian Occupation. Donald D. Cox and Donald M. Lewis. Pp. iii +29 . Albany, New York: The University of the State of New York-The State Education Departments, 1965). Prehistoric Indian sites are widely distributed in the immediate area, and the authors have also tried to incorporate this occupational evidence into the climatic 